\title{
sciendo
}

\section{PARTIAL REPLACEMENT OF CONCENTRATE WITH OLIVE CAKE IN DIFFERENT FORMS IN THE DIET OF LACTATING BARKI EWES AFFECTS THE LACTATIONAL PERFORMANCE AND FEED UTILIZATION}

\author{
Fatma I. Hadhoud ${ }^{1}$, Ahmed E. Kholif ${ }^{1 \star}$, Ahmed M. Abd El Tawab ${ }^{1}$, Mahmoud M. Shaaban², \\ Mohamed M.M. Mostafa ${ }^{2}$, Hossam M. Ebeid ${ }^{1}$, Osama H. Matloup ${ }^{1}$ \\ 'Dairy Science Department, National Research Centre, 33 Bohouth St. Dokki, Giza, Egypt \\ ${ }^{2}$ Biological Applications Department, Nuclear Research Center, Atomic Energy Authority, Inshas, \\ Cairo, Egypt \\ •Corresponding author: ae_kholif@live.com, ae.kholif@nrc.sci.eg
}

\begin{abstract}
The present experiment aimed to evaluate the inclusion of dried olive cake treated or untreated with fibrolytic enzyme, partially replacing concentrates in the diet of ewes. Forty lactating Barki ewes, weighing $37.1 \pm 4.0 \mathrm{~kg}$, were assigned into four treatments $(\mathrm{n}=10)$ in a complete randomized design for 9 weeks. Ewes were stratified according to parity $(2 \pm 1$ parity $)$ and previous milk production $(615 \pm 11 \mathrm{~g} / \mathrm{d})$. The control diet consisted of concentrates and corn fodder at 60:40, respectively. For the experimental diets, $30 \%$ of the concentrates was replaced with dried olive cake (DOC treatment), olive cake silage (SOC treatment) or olive cake silage treated with fibrolytic enzymes (ESOC treatment). Without affecting intake, DOC, SOC and ESOC diets enhanced $(\mathbf{P}<0.05)$ dry matter, organic matter and non-structural carbohydrate digestibility; however, ESOC diets increased $(P<0.05)$ neutral detergent fiber and acid detergent fiber digestibility. Additionally, DOC, SOC and ESOC diets increased $(\mathrm{P}<0.05)$ ruminal total volatile fatty acids, acetate and propionate without affecting ruminal $\mathrm{pH}$ and ammonia-N concentration. The ESOC diet increased serum glucose concentration $(\mathrm{P}=\mathbf{0 . 0 1 9})$. Both of SOC and ESOC diets increased $(\mathrm{P}<0.05)$ daily milk production and energy corrected milk as well as milk fat concentration $(P=0.028)$. All of DOC, SOC and ESOC increased $(\mathrm{P}<0.05)$ feed (milk) efficiency compared with the control diet. It is concluded that $30 \%$ of concentrates can be replaced with olive cake without negative effects on performance but with better performance when olive cake was ensiled with or without fibrolytic enzymes.
\end{abstract}

Key words: agricultural byproducts, digestibility, fibrolytic enzymes, lactational performance, olive cake, ruminal fermentation

The utilization of unconventional feeds and food byproducts in animal feeding has a great importance to decrease the cost of feeding and increase the profitabil- 
ity (Khattab et al., 2013; Kholif et al., 2014; Khattab and El Tawab, 2018; Sallam et al., 2020). Olive is a major crop in Mediterranean countries (Berbel and Posadillo, 2018). The extraction of oil from olive is associated with the production of large amounts of byproducts mainly olive cake. It is difficult to dispose of olive cake and may have a negative environmental impact (Berbel and Posadillo, 2018).

The nutritive value of olive cake can support maintenance requirement of ruminant. Olive cake consists of olive pulp, skin, stone and water (Molina-Alcaide and Yáñez-Ruiz, 2008; Berbel and Posadillo, 2018). It contains low protein (4.8 to $10.6 \%$ ) and high fiber (about 58\% neutral detergent fiber (NDF), 46\% acid detergent fiber (ADF) and 24\% lignin, DM basis) and oil (18-25\% of DM) contents (Cabiddu et al., 2004; Molina-Alcaide and Yáñez-Ruiz, 2008; Abbeddou et al., 2011) with a low digestibility (Molina-Alcaide and Yáñez-Ruiz, 2008). Moreover, olive cake contains high oleic acid content (Berbel and Posadillo, 2018) which may enhance the nutritional value of animal products (milk and meat) for human consumption. The chemical composition of olive cake makes it a low-quality feedstuff. Therefore, efficient utilization of the olive cake as a ruminant feed requires upgrading its nutritional value before feeding. Different approaches have been evaluated to enhance the nutritive value of olive cake. Chemical treatment increased nutrient digestibility of olive cake (Nefzaoui and Vanbelle, 1986; Keleş, 2015). Additionally, ensiling (Hadjipanayiotou, 1999; Cabiddu et al., 2004), and treatment with exogenous fibrolytic enzymes (Awawdeh and Obeidat, 2013) showed variable results.

Studies have shown that olive cake can be included in the diet of lactating sheep up to $30 \%$ without negativ effects on feed utilization or milk production (Cabiddu et al., 2004; Abbeddou et al., 2011; Vargas-Bello-Pérez et al., 2013). In another experiment (Chiofalo et al., 2004), olive cake at $20 \%$ of the diet increased milk production of ewes. The main problem of feeding olive cake is the variable chemical composition, and the high content of raw fiber, tannin and phenols, causing unfavorable effects on digestion and cellulolytic activity of ruminal microorganisms (Mioč et al., 2007). Therefore, fibrolytic enzyme, such as cellulase and xylanase, administration can enhance its utilization and increase fiber digestibility (Abd El Tawab et al., 2015; Salem et al., 2015 b; Morsy et al., 2016; Kholif et al., 2018 c). Treatment with fibrolytic enzymes showed promising results to enhance the nutritive value of poor quality feeds (Kholif et al., 2017 b) and enhance the performance of lactating animals (Kholif et al., 2018 c; Azzaz et al., 2020).

Therefore, the aim of the present study was to evaluate the effects of replacing $30 \%$ of concentrates (equal to $18 \%$ of total diets) in the diet of lactating Barki sheep at three forms including dried olive cake, ensiled olive cake without additives or ensiled with fibrolytic enzymes. We hypothesized that feeding a diet containing olive cake with or without fibrolytic enzyme treatment might improve milk production and feed utilization without negative effects on blood biochemistry. Additionally, we hypothesized that the treatment with fibrolytic enzymes might improve the utilization of olive cake through increasing fiber digestibility. 


\section{Material and methods}

\section{Study location}

The experiment was carried out at the Animal Production Experimental Farm, Nuclear Research Center (Egypt), whereas analyses were performed at the Laboratory of Dairy Animal Production, National Research Centre (Egypt). Ewes were managed in accordance with the Guide for the Care and Use of Agricultural Animals in Agricultural Research and Teaching (Federation of Animal Science Societies; Champaign, IL, USA).

\section{Enzymes and ensiling}

Fibrolytic enzymes were produced from anaerobic bacteria (Clostridium butyricum) at Dairy Science Department, National Research Centre (Egypt). Each gram of enzymes contains $5000 \mathrm{IU} / \mathrm{g}$ of cellulase. Full description about production of enzyme can be founded in Khattab et al. (2017, 2019).

Fresh olive cake (Olea europaea) was collected from Modern Olive Oil Extraction Plant at Al Salhiya Agricultural Company, Al Sharqia (Egypt). Crude olive cake was prepared simply by adjusting the moisture content to $65-70 \%$ before ensiling. Olive cake silage was prepared by spraying fresh olive cake with four liter of enzyme solution per ton DM of olive cake. Another olive silage was prepared without enzyme treatment. The material was ensiled in plastic bags for two months before feeding to the ewes.

Before feeding, silage quality was evaluated by measuring $\mathrm{pH}$, ammonia- $\mathrm{N}$, acetic, butyric and lactic acid concentrations. A homogenized sample of silage (200 $\mathrm{g}$ fresh weight) was mixed with $800 \mathrm{~mL}$ of distilled water and homogenized for 3 min with a laboratory blender and then filtrated through 4 layers of cheesecloth. The $\mathrm{pH}$ value was measured by using an $\mathrm{HI} 9321$ microprocessor $\mathrm{pH} / \mathrm{mV} /{ }^{\circ} \mathrm{C}$ bench meter (Hanna ${ }^{\circledR}$ Instrument, Singapore). Ammonia-N concentration was determined by Kjeldahl distillation according to AOAC (1997). Before determination of acetic, butyric and lactic acid concentrations, samples ( $40 \mathrm{~mL}$ silage fluid) were centrifuged for $15 \mathrm{~min}$ at $6000 \times \mathrm{g}$ at $4{ }^{\circ} \mathrm{C}$ to prevent loss of volatiles. The concentrations of acetic, butyric and lactic acids were determined using gas-liquid chromatography (model 5890, HP, LittleFalls, DE, USA) and lactic acid (L-1750; Sigma-Aldrich, ON, Canada) was used as a standard (Abd El Tawab et al., 2020).

\section{Ewes, diets and experimental design}

One week before lambing, forty Barki ewes with $37.1 \pm 4.0 \mathrm{~kg}$, were randomly assigned to four experimental treatments $(n=10)$ in a complete randomized design for 9 weeks. Ewes were stratified according to parity ( $2 \pm 1$ parity) and previous milk production $(615 \pm 11 \mathrm{~g} / \mathrm{d})$. Ewes were individually housed in pens $\left(1.5 \mathrm{~m}^{2} / \mathrm{ewe}\right)$, with free access to water. Individual ewes were weighed weekly on a digital multi-purpose platform scale. Ewes were offered the experimental diets to meet their nutrient requirements according to NRC (2007). Adjustments were made to the diets to ensure collection of orts. The control diet was based on (per kg DM): 600 $\mathrm{g}$ of concentrates feed mixture and $400 \mathrm{~g}$ corn fodder (Zea mays L.). In the other diets, 
$30 \%$ of concentrates was replaced with dried olive cake (DOC treatment), olive cake silage (SOC treatment) or olive cake silage treated with fibrolytic enzymes (ESOC treatment). Diets were offered, twice a day, at 06:00 and 17:00 h. Ewes were offered the portion of concentrate feed mixture, followed by corn fodder. The ingredients and chemical composition of the diets and ingredients are shown in Tables 1 and 2.

\section{Nutrient intake, digestibility, and chemical analyses}

During the whole experiment, feed intake was recorded daily for each ewe by weighing the offered diets and refusals from the previous day (Abo El-Nor and Khattab, 2012). Two nutrient digestibility trials were carried out at the 5th and the 9th weeks, using acid insoluble ash as an internal indigestible marker (Sales and Janssens, 2003). Coefficients of digestion were calculated according to Ferret et al. (1999). Fecal grab samples were collected from ewes, twice daily during the collection weeks (5th and 9th weeks) at 07:00 and 18:00 h, dried at $105^{\circ} \mathrm{C}$ in a forced-air oven for $12 \mathrm{~h}$ (AOAC, 1997), and pooled by ewe. The composited fecal samples, feed and orts samples were ground to pass a 1-mm screen using a Wiley mill grinder (Arthur H. Thomas, Philadelphia, PA, USA), and retained for later determination of compositional contents.

Table 1. Ingredients and chemical composition of diets fed to the lactating Barki ewes

\begin{tabular}{|c|c|c|c|c|}
\hline & \multicolumn{4}{|c|}{ Diets $^{1}$} \\
\hline & Control & $\mathrm{DOC}$ & SOC & ESOC \\
\hline \multicolumn{5}{|l|}{ Ingredients (g/kg DM) } \\
\hline corn fodder & 400 & 400 & 400 & 400 \\
\hline yellow corn & 132 & 60 & 60 & 60 \\
\hline sugar beet pulp & 186 & 114 & 114 & 114 \\
\hline wheat bran & 162 & 114 & 114 & 114 \\
\hline soya bean meal & 42 & 54 & 54 & 54 \\
\hline undecorticated cotton seed cake & 60 & 60 & 60 & 60 \\
\hline dried olive cake & 0 & 180 & 0 & 0 \\
\hline silage of olive cake & 0 & 0 & 180 & 0 \\
\hline silage of olive cake treated with enzyme & 0 & 0 & 0 & 180 \\
\hline sodium chloride & 6 & 6 & 6 & 6 \\
\hline mineral/vitamin mixture ${ }^{2}$ & 2.4 & 2.4 & 2.4 & 2.4 \\
\hline dicalcium phosphate & 9 & 9 & 9 & 9 \\
\hline sodium bicarbonate & 0.6 & 0.6 & 0.6 & 0.6 \\
\hline \multicolumn{5}{|l|}{ Chemical composition (g/kg DM) } \\
\hline dry matter & 897 & 913 & 883 & 897 \\
\hline organic matter & 930 & 932 & 932 & 935 \\
\hline crude protein & 106 & 114 & 103 & 116 \\
\hline ether extract & 64 & 65 & 74 & 68 \\
\hline non-structural carbohydrates & 254 & 215 & 240 & 225 \\
\hline neutral detergent fiber & 506 & 538 & 514 & 526 \\
\hline acid detergent fiber & 268 & 312 & 302 & 311 \\
\hline
\end{tabular}

${ }^{1}$ Diets: Thirty percent of the concentrates was replaced with dried olive cake (DOC treatment), olive cake silage (SOC treatment) or olive cake silage treated with fibrolytic enzymes (ESOC treatment).

${ }^{2}$ Provided per kilogram of the diet: $30 \mathrm{mg} \mathrm{Zn}$ as $\mathrm{Zn} \mathrm{SO}_{4} .7 \mathrm{H}_{2} \mathrm{O} ; 20 \mathrm{mg} \mathrm{Mn}$ as $\mathrm{MnSO}_{4} \cdot \mathrm{H}_{2} \mathrm{O} ; 0.5 \mathrm{mg} \mathrm{I}$ as KI ; $0.1 \mathrm{mg} \mathrm{Co}$ as $\mathrm{CoCl}_{2} ; 0.1 \mathrm{mg} \mathrm{Se}$ as $\mathrm{Na}_{2} \mathrm{SeO}_{3}, 1500 \mathrm{IU}$ vitamin $\mathrm{A} ; 250 \mathrm{IU}$ vitamin D and 16 IU vitamin E. 


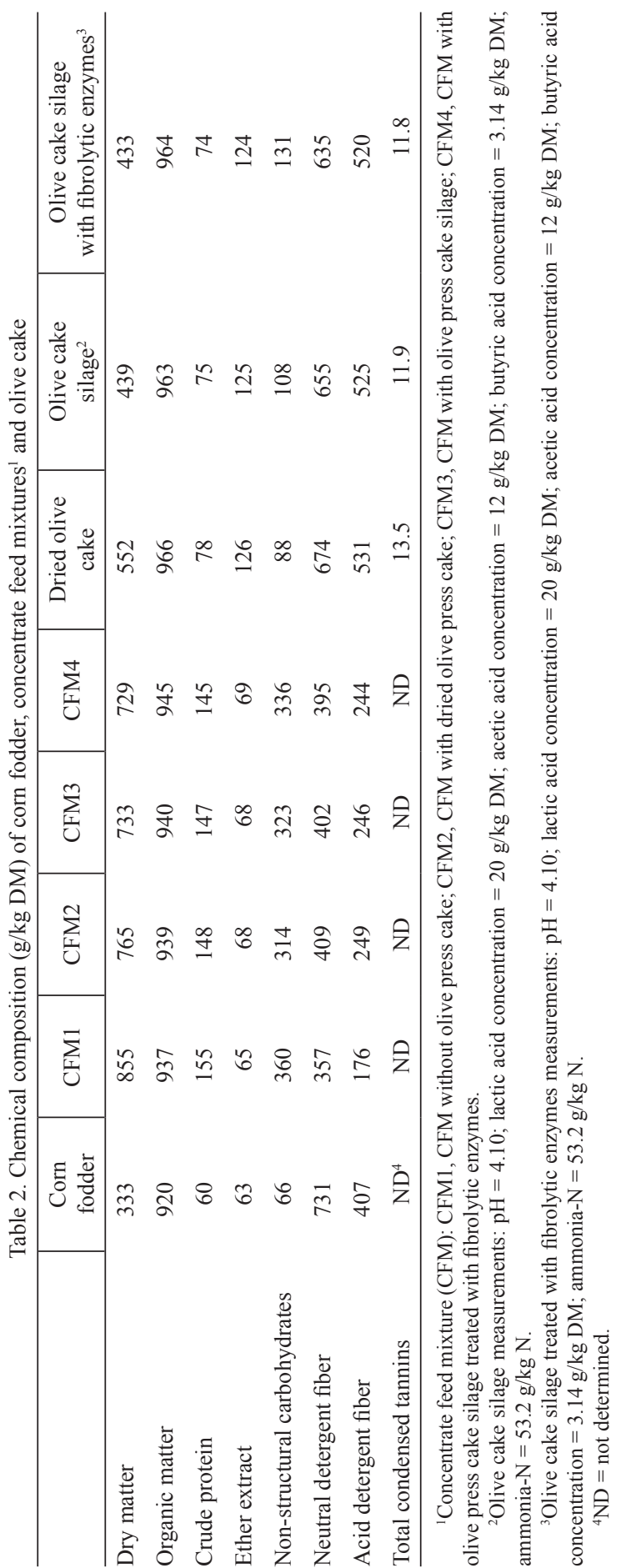


Feed, orts, and fecal samples were analyzed for ash after heating samples in a muffle furnace at $550^{\circ} \mathrm{C}$ for $3 \mathrm{~h}$ (method ID 942.05), $\mathrm{N}$ using Kjeldahl method (method ID 954.01), and ether extract (EE) using diethyl ether in a Soxhlet extractor (method ID 920.39) according to AOAC (1997) official methods. Neutral detergent fiber was determined as reported previously (Van Soest et al., 1991) by using sodium sulfite instead of alpha-amylase. Acid detergent fiber (method ID 973.18) was analyzed according to AOAC (1997); (method ID 973.18) after digestion with sulfuric acid and cetyl trimethylammonium bromide, and expressed exclusive of residual ash. Lignin was analyzed by solubilization of cellulose with sulfuric acid in the ADF residue according to Van Soest et al. (1991). Organic matter (OM) and non-structural carbohydrate (NSC) were calculated.

\section{Sampling and analyses of ruminal fluid}

On the last day of the 5th and 9th weeks of the experiment, ruminal contents were sampled at $3 \mathrm{~h}$ after the morning feeding from all ewes to determine the $\mathrm{pH}$ and concentration of ammonia-N and individual volatile fatty acids (VFA). Ruminal contents (approximately $100 \mathrm{~mL}$ ) were collected by using a stomach tube, and the composite samples taken from each ewe were strained through 4 layers of cheesecloth. To avoid saliva contamination of ruminal content, the first $50 \mathrm{~mL}$ of the rumen fluid sample was discarded. The $\mathrm{pH}$ of ruminal fluid was measured immediately using a pH meter (HI98127 pHep ${ }^{\circledR}$ pH/Temperature Tester, Hanna ${ }^{\circledR}$ Instruments, Villafranca Padovana PD, Italy).

A subsample of $5 \mathrm{~mL}$ was preserved in $5 \mathrm{~mL}$ of $0.2 \mathrm{M} \mathrm{HCl}$ for ammonia-N analysis. For total VFA analysis, $0.8 \mathrm{~mL}$ of the ruminal liquor was mixed with $0.2 \mathrm{~mL}$ of a solution containing $250 \mathrm{~g}$ of metaphosphoric acid/L. All samples were stored at $-20^{\circ} \mathrm{C}$, until analyzed in the laboratory for the concentration of ruminal ammonia$\mathrm{N}$ according to AOAC (1997) and individual VFA by gas-liquid chromatography (Varian 3700; Varian Specialties Ltd, Brockville, Ontario, Canada). The separation process was carried out with a capillary column $(30 \mathrm{~m} \times 0.25 \mathrm{~mm}$ internal diameter, 1-mm film thickness, Supelco Nukol; Sigma-Aldrich, Mississauga, Ontario, Canada) using a flame ionization detection. Methane $\left(\mathrm{CH}_{4}\right)$ production $(\mathrm{mmol} / \mathrm{L})$ was calculated as: $\mathrm{CH}_{4}=0.45$ (acetate) -0.275 (propionate) +0.4 (butyrate) as described by Moss et al. (2000).

\section{Sampling and analyses of blood serum}

On the last day of the 5th and 9th weeks of the experiment, blood samples (10 $\mathrm{mL}$ ) were taken $4 \mathrm{~h}$ after feeding from the jugular vein of all ewes into plain clean dry tubes without anticoagulants. Blood samples were centrifuged at $4,000 \times \mathrm{g}$ for $20 \mathrm{~min}$. Serum was separated into 2-mL clean dried Eppendorf tubes and frozen at $-20^{\circ} \mathrm{C}$, until analysis using specific kits (Stanbio Laboratory, Boerne, TX, USA) and following manufacturer instructions. Serum triiodothyronine $\left(\mathrm{T}_{3}\right)$ and thyroxine $\left(\mathrm{T}_{4}\right)$ concentrations were determined according to the procedure specified with the RIA coated tubes kits produced by RIAKEYTUBE II ${ }^{\circledR}$, Republic of Korea (Code No: RT10\&RT02). 


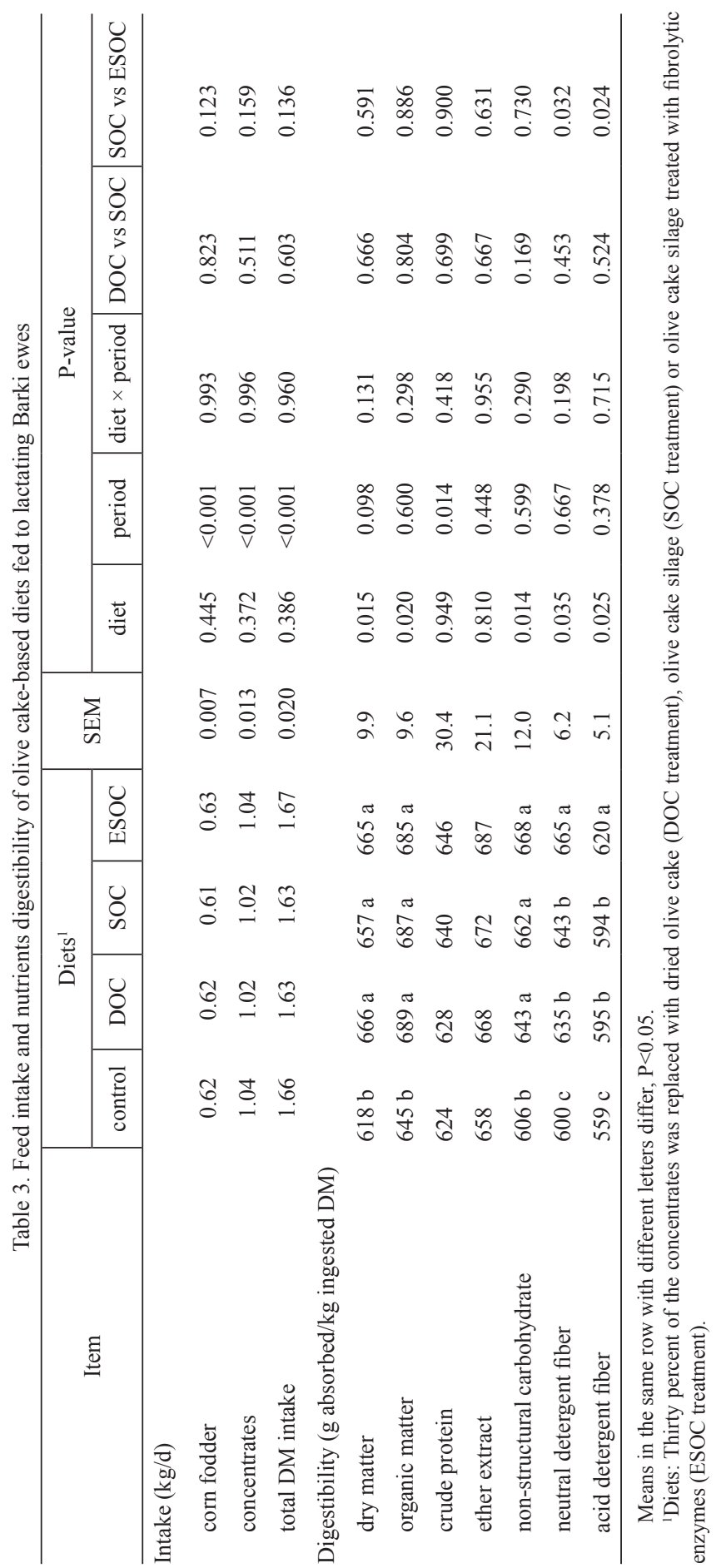




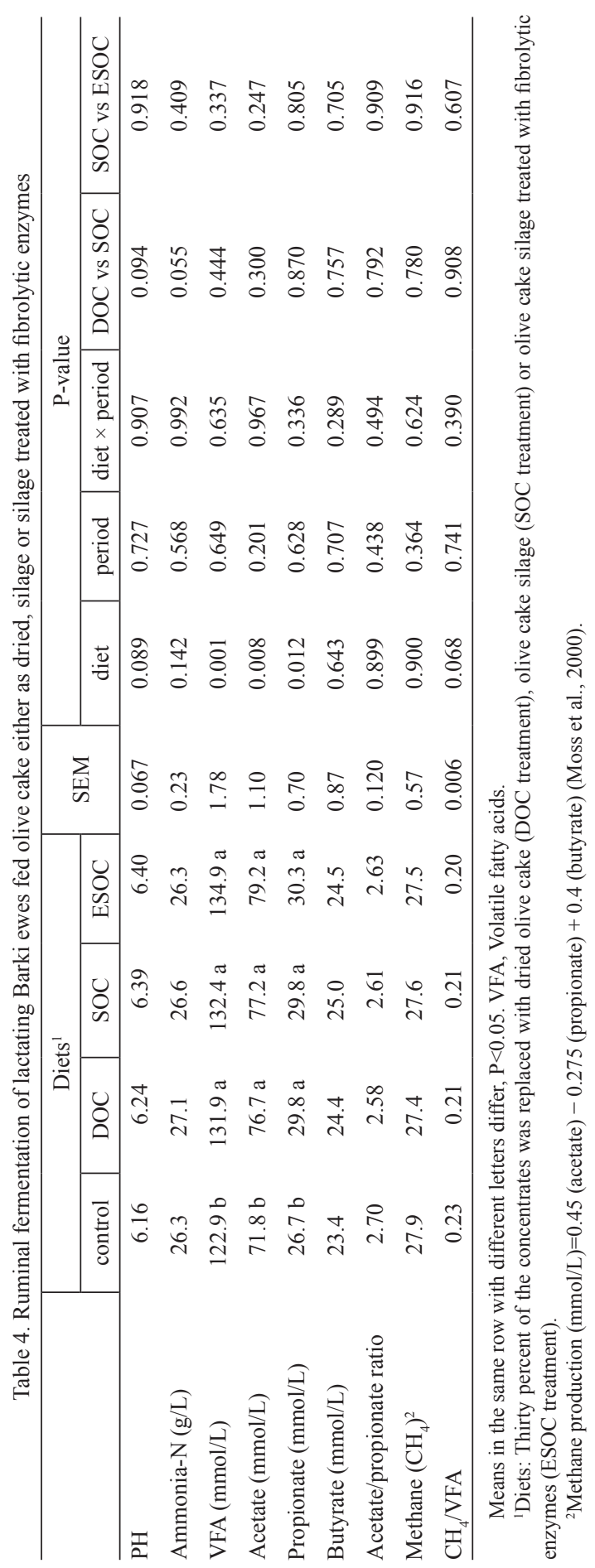




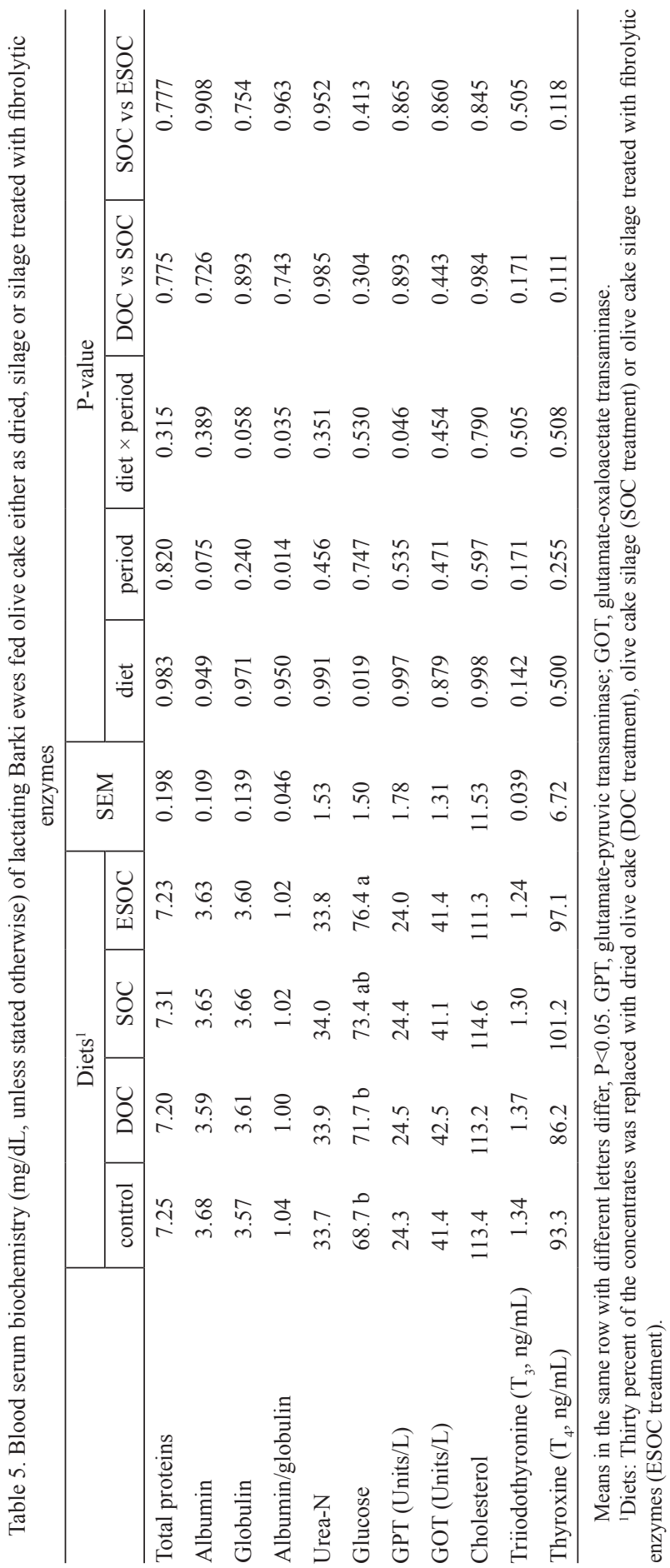




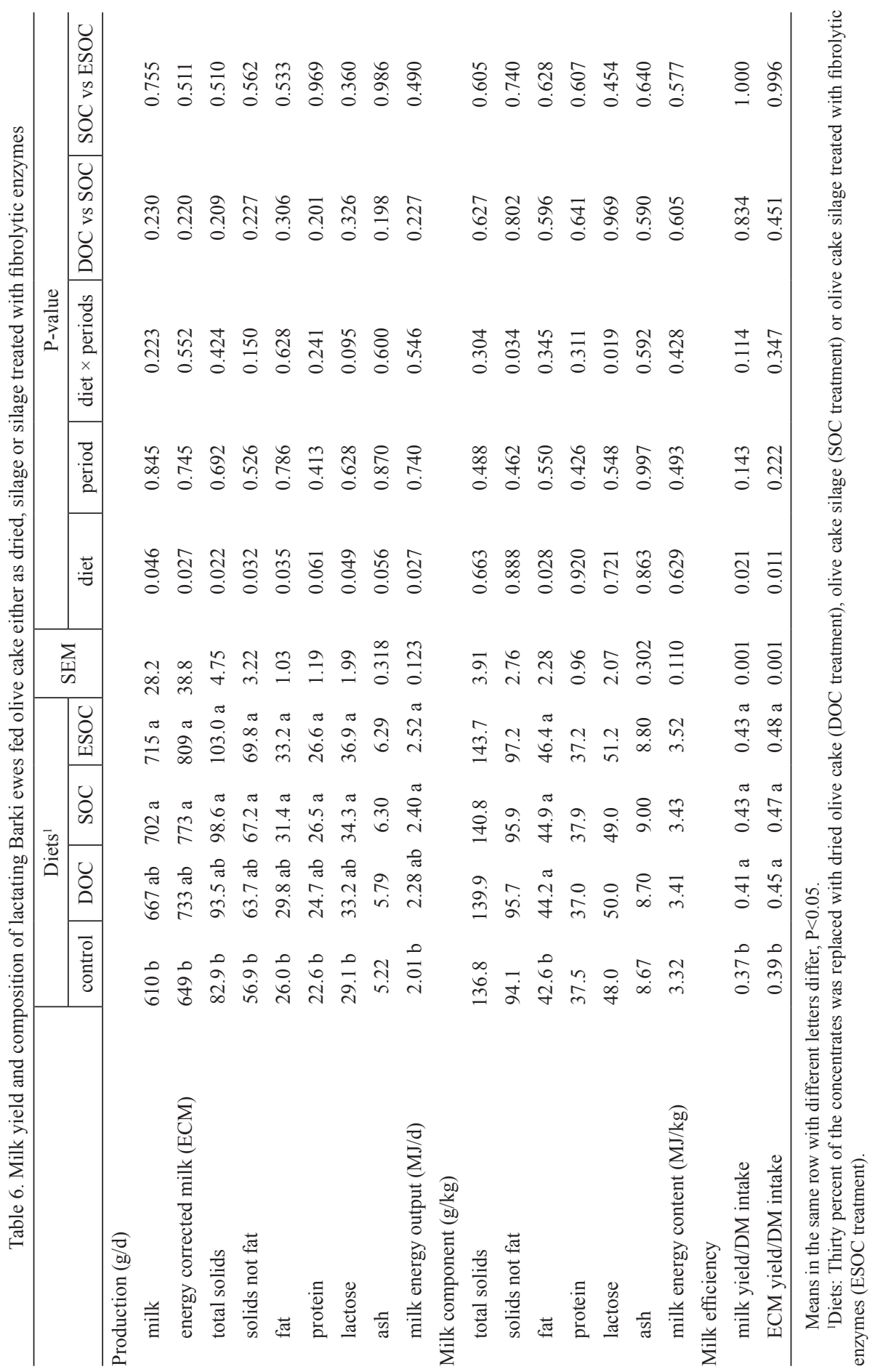




\section{Milk sampling, and milk composition}

Ewes were milked weekly during the last three days of each week by hand twice daily at $06: 00$ and 18:00 h, and samples (10\% of recorded milk yield) were collected at each milking (Morsy et al., 2015). A mixed sample of morning and evening milk was taken daily. Milk samples were analyzed for total solids, fat, protein, and lactose, using infrared spectrophotometry (Milkotester LM2, Belovo, Bulgaria). The ash content of milk was determined after heating a milk sample in a muffle furnace at $550^{\circ} \mathrm{C}$ for $8 \mathrm{~h}$.

Average yields (g/d) of each milk component were calculated for individual ewes by multiplying milk yield by the component content $(\mathrm{g} / \mathrm{kg})$ of milk. The gross energy content of milk was calculated according to Tyrrell and Reid (1965) as: milk energy content $(\mathrm{MJ} / \mathrm{kg})=4.184 \times 2.204 \times[41.63 \times$ fat $(\mathrm{g} / 100 \mathrm{~g})+24.13 \times$ protein $(\mathrm{g} / 100$ $\mathrm{g})+21.60 \times$ lactose $(\mathrm{g} / 100 \mathrm{~g})-11.72) / 1000]$. Milk energy output $(\mathrm{MJ} /$ day $)$ was calculated as milk energy $(\mathrm{MJ} / \mathrm{kg}) \times$ milk yield $(\mathrm{kg} /$ day $)$. Energy corrected milk $(\mathrm{ECM})$ was calculated according to Sjaunja et al. (1991) as: ECM $(\mathrm{kg} /$ day $)=$ milk $(\mathrm{kg} /$ day $)$ $\times[38.3 \times$ fat $(\mathrm{g} / \mathrm{kg})+24.2 \times$ protein $(\mathrm{g} / \mathrm{kg})+16.54 \times$ lactose $(\mathrm{g} / \mathrm{kg})+20.7] / 3140$.

\section{Statistical analyses}

Data for intake, nutrient digestibility, ruminal fermentation, blood profile, and milk yield and composition were analyzed using the PROC MIXED procedure of SAS (Version 9.4, SAS Inst., Inc., Cary, NC), with week as a repeated measures and individual animal as the experimental unit. The model included: $\mathrm{Y}_{\mathrm{ijk}}=\mu+\mathrm{T}_{\mathrm{i}}+\mathrm{P}_{\mathrm{j}}+$ $(\mathrm{T} \times \mathrm{P})_{\mathrm{ij}}+\mathrm{E}_{\mathrm{ijk}}$, where $\mathrm{Y}_{\mathrm{ijk}}$ is each individual observation for a given variable, $\mu$ is the overall mean, $\mathrm{T}_{\mathrm{i}}$ is the treatment effect, $\mathrm{P}_{\mathrm{j}}$ is the period effect, $(\mathrm{T} \times \mathrm{P})_{\mathrm{ij}}$ is the interaction between treatment and period, and $\mathrm{E}_{\mathrm{ijk}}$ is the residual error. Two covariance structures were considered in the REPEATED statement in PROC MIXED: compound symmetry (cs) and auto-regressive (AR(1)). The error structure with the lowest Akaike information criteria that fits statistics was selected for the model. When the $F$-test was significant at $\mathrm{P}<0.05$, means were compared by applying the probability of difference option of the least squares means statement. In addition, means were also compared using single-degree of freedom orthogonal contrasts (i.e., DOC vs. SOC and SOC vs. ESOC). The week effect and treatment $\times$ week interactions were non-significant (i.e., $\mathrm{P}>0.05$ ) for most of the measurements; thus, only the main effects of treatments were reported.

\section{Results}

\section{Nutrient intake and digestibility}

Treatments did not affect intake of fresh corn fodder, concentrates or total feed intake (Table 3). Compared with the control diet, DOC, SOC and ESOC increased the digestibility of $\mathrm{DM}(\mathrm{P}=0.015), \mathrm{OM}(\mathrm{P}=0.02)$ and NSC $(\mathrm{P}=0.014)$. Replacing the concentrates with ESOC increased NDF $(\mathrm{P}=0.035)$ and $\mathrm{ADF}(\mathrm{P}=0.025)$ digestibility compared with the other treatments. 


\section{Ruminal fermentation}

Diets did not affect ruminal $\mathrm{pH}$, ammonia-N concentration, butyrate, acetate/propionate ratio, $\mathrm{CH}_{4}$ or $\mathrm{CH}_{4} / \mathrm{VFA}$ (Table 4). The DOC, SOC and ESOC diets increased ruminal total VFA $(\mathrm{P}=0.001)$, acetate $(\mathrm{P}=0.008)$ and propionate $(\mathrm{P}=0.012)$ compared with the control treatment. No difference was observed between DOC, SOC and ESOC treatments for total or individual VFA.

\section{Blood metabolites}

Diets did not affect the concentration of total proteins, albumin, globulin, albumin/globulin ratio, urea-N, glutamate-pyruvic transaminase (GPT), glutamate-oxaloacetate transaminase (GOT), cholesterol $\mathrm{T}_{3}$ and $\mathrm{T}_{4}$ (Table 5). The ESOC diet increased serum glucose concentration $(\mathrm{P}=0.019)$ compared with the control and DOC diets.

\section{Performance}

Figure 1 shows body weight of ewes fed a control and experimental diets. Body weight did not differ between treatments throughout the experimental period $(\mathrm{P}=0.866)$.

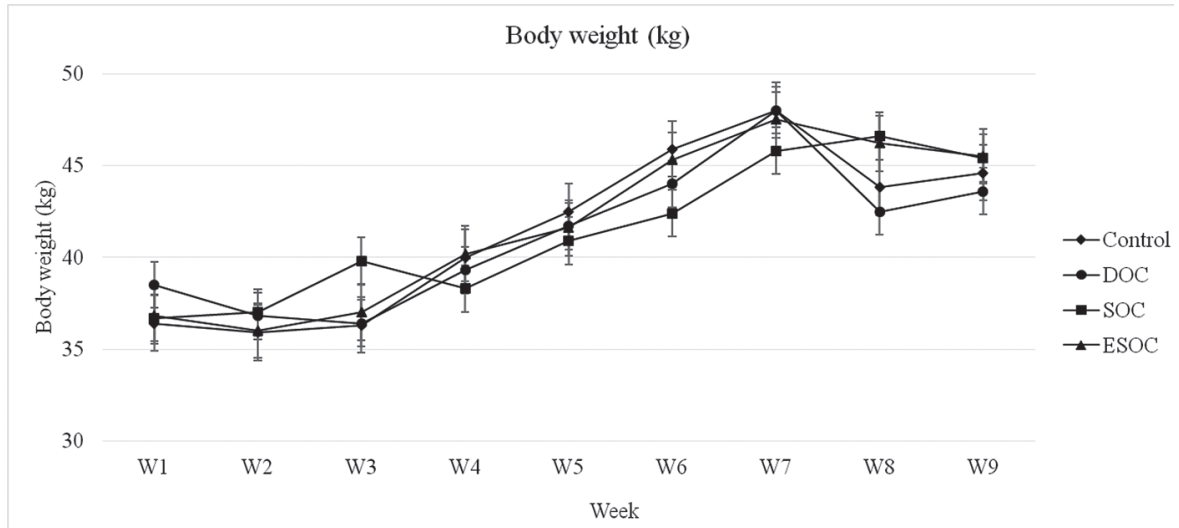

Figure 1. Body weight of ewes fed a control diet based on corn fodder and concentrates feed mixture at 40:60 (DM basis). Thirty percent of the concentrates in the control diet was replaced with dried olive cake (DOC treatment), olive cake silage (SOC treatment) or olive cake silage treated with fibrolytic enzymes (ESOC treatment) over 9-week experiment. $(\mathrm{P}=0.866, \mathrm{SEM}=0.492)$

Each of SOC and ESOC diets increased $(\mathrm{P}<0.05)$ daily productions of milk, ECM and yields of milk components compared with the control diet (Table 6). Diets did not affect the concentration of milk total solids, solids not fat, protein, lactose, ash and milk energy; however, both of SOC and ESOC diets increased milk fat concentration $(\mathrm{P}=0.028)$. Diets of DOC, SOC and ESOC increased feed (milk) efficiency calculated as milk yield/DM intake $(\mathrm{P}=0.021)$ or $\mathrm{ECM}$ yield/DM intake $(\mathrm{P}=0.011)$ compared with the control diet. 


\section{Discussion}

\section{Nutrient intake and digestibility}

In the present study, replacing concentrates with olive cake, at any form, did not affect feed intake, revealing unaffected feed palatability (Abdel-Aziz et al., 2015). Vargas-Bello-Pérez et al. (2013) observed unaffected feed intake of sheep fed diet containing olive cake at 10 or $25 \%$ of diet. Conversely, Cabiddu et al. (2004) observed negative effect with feeding olive cake on feed intake to lactating cows. However, increased feed intake was noted when sheep were fed olive cake as pellets (116

$\mathrm{g} \mathrm{DM} / \mathrm{BW}^{0.75} /$ day) than as silage $\left(99 \mathrm{~g} \mathrm{DM} / \mathrm{BW}^{0.75} /\right.$ day) due to the reduced retention time of olive cake in the rumen as a result of reducing particle size (Nefzaoui and Vanbelle, 1986). Variability between experiments is mainly due to differences in animal species, the chemical composition, oil extraction process, degree of extraction, level of residual oil and proportion of different physical components (stone, skin, pulp, water) (Habeeb et al., 2017).

It is known that nutrient digestibilities of olive cake are low and variable (Molina-Alcaide and Yáñez-Ruiz, 2008); however in the present experiment, replacing concentrates with DOC, SOC or ESOC increased the digestibility of DM, OM and NSC. Awawdeh and Obeidat (2013) reported that it is difficult and probably inappropriate to compare "specific" values of nutrient digestibility from previous studies with the present values of nutrient digestibility due to inherent differences among studies in terms of experimental settings (basal diet and level of intake), type and level of tested olive cake, and techniques for estimating digestibility. Improved nutrient digestibility may be related to enhanced microbial activity in the rumen and improved ruminal fermentation (Molina-Alcaide and Yáñez-Ruiz, 2008; Valdes et al., 2015). Decreasing ruminal protozoa (Molina-Alcaide and Yáñez-Ruiz, 2008) and improving microbial protein synthesis in the rumen (Firkins, 1997) with feeding olive cake due to the high content of unsaturated fatty acids found in olive cake have been documented. Additionally, Molina-Alcaide and Yáñez-Ruiz (2008) reported that feeding olive cake might enhance the rumen microbial population, especially on cellulolytic activity depending on its oil content.

Expectedly, olive cake silage treated with fibrolytic enzymes increased fiber digestibility probably due to breaking off cross linkages between lignin and cell wall components and solubilizing cell wall contents (mainly hemicellulose) by fibrolytic enzymes (Khattab et al., 2011; Kholif et al., 2017 b). Fibrolytic enzymes can change the rate of ruminal degradability of the potentially digestible NDF (Yang et al., 1999; Togtokhbayar et al., 2015) and increase the activity and number of non-fibrolytic and fibrolytic bacteria population in rumen fluid (Wang et al., 2001).

\section{Ruminal fermentation}

Replacing the concentrates with olive cake did not affect ruminal $\mathrm{pH}$, which were above the value (5.6) indicated by Ryle and Ørskov (1990) for digestion of fiber. In line with the present results, Awawdeh and Obeidat (2013) observed that feeding olive cake to lambs at $10.1 \%$ of total diet did not affect ruminal $\mathrm{pH}$. Additionally, feeding olive cake did not affect ruminal ammonia-N concentration; however, all 
noted concentrations were above the lowest level of $5 \mathrm{~g}$ ammonia-N/L indicated by Satter and Slyter (1974) for optimum ruminal microbial proliferation and activity. Nefzaoui and Vanbelle (1986) observed unaffected ruminal ammonia-N concentration in lambs fed either hay or ensiled olive cake.

Olive cake containing diets increased ruminal total VFA which may be related to the enhanced nutrient digestion, especially OM, fiber and NSC (Elghandour et al., 2015, 2016; Salem et al., 2015 a). The concentration of VFA depends mainly on fiber and NSC concentrations in diet, feed digestion and ruminal microbiome activity (Flatt et al., 1956; Rojo et al., 2015). Increasing VFA concentration reveals that the level of dietary fiber in olive cake enhanced cellulolytic activity in the rumen (Lu et al., 2008). Moreover, feeding olive cake increased ruminal acetate as a result of the enhanced fiber digestion of the diets. Increasing ruminal acetate favors the production of milk fat (Abd El Tawab et al., 2020), as noted in the present experiment. Replacing the concentrates with olive cake increased ruminal propionate, which is paralleled with the result of OM and NSC digestibility via the fermentation of sugars released by cell wall hydrolysis by ruminal enzymes making OM and NSC digestibility as the main reasons for increasing ruminal propionate (Morsy et al., 2018; Kholif, 2019). Increasing propionate production in the rumen elevates precursor's availability and improves nutrient utilization and increases milk production and milk lactose content (Rigout et al., 2003), as propionate is the primary gluconeogenic VFA required for lactose biosynthesis (Linn, 1974; Kholif et al., 2018 a, Kholif, 2019).

Ensiling with or without fibrolytic enzymes did not affect ruminal fermentation as the results of ESOC treatment did not differ from those of SOC treatment. We hypothesized that fibrolytic enzyme treatment may increase acetate concentration as a result of enhancing fiber digestibility but this was not observed without a clear reason.

\section{Blood metabolites}

All studied blood metabolites were within the established reference ranges for ewes, revealing the absence of negative effects of the treatments on blood chemistry (Rivero et al., 2016). Replacing the concentrates with olive cake did not affect the concentrations of total proteins, albumin, globulin, albumin/globulin ratio and urea$\mathrm{N}$ suggesting minimal effects on the nutritional status of ewes, minimal protein catabolism, and normal kidney function. Additionally, feeding olive cake did not affect the concentrations of serum GPT, GOT and cholesterol indicating minimal effects of the treatments on the health of the livers of ewes (Olafadehan et al., 2014).

Ensiling of olive cake with fibrolytic enzymes increased serum glucose concentration compared with the control or dried olive cake as a result of increasing propionate production because more than half of the blood glucose in ruminants is synthesized from propionate in the liver (Huntington et al., 2006; Kholif et al., 2017 a). The improved digestibility of OM can be another reason of the increased glucose because results of OM digestibility are parallel with those of blood glucose. Such results indicate marginal body fat mobilization and enhanced ewe's energy status. 


\section{Performance}

The major finding of the current study was that ensiling of olive cake without or with fibrolytic enzymes increased production of daily milk (by 17.5 and $17.8 \%$, respectively) and ECM (by 18.2 and $27.1 \%$, respectively). This reflects the cumulative effect of improved nutrient digestion and altered ruminal fermentation (Kholif et al., 2021) with feeding olive cake (Chiofalo et al., 2004). Increasing milk production without affecting feed intake was reflected as enhanced feed (milk) efficiency calculated as milk yield/DM intake by $10.8,16.2$ and $16.2 \%$ and calculated as ECM yield/DM intake by 15.4, 20.5 and 23.1\%, respectively for DOC, SOC and ESOC treatments compared with the control diet. Chiofalo et al. (2004) noted increased milk production with feeding lactating goats on diet containing $20 \%$ olive cake ( $649 \mathrm{~g}$ vs. $772 \mathrm{~g}$ per animal per day). Increased feed digestion and utilization by rumen microbiome and minimized calorie and protein losses during rumen fermentation can be considered as the main reasons for the increased milk yield (Azzaz et al., 2020). In the present experiment, increased concentration of ruminal propionate, which is the precursor for gluconeogenesis and lactose synthesis, increased glucogenic precursors that have favorable effects on milk yield (Rigout et al., 2003). As previously noted, increasing blood glucose indicates a good index of energy status of a diet, and can be considered as another reason for the increased milk production (Rigout et al., 2003). Rigout et al. (2003) reported a curvilinear increased milk production as a result of improved glucogenic precursors in dairy cows.

Replacing concentrates with olive cake did not affect the concentration of milk components; however, ensiled olive cake with or without fibrolytic enzymes increased milk fat concentrations by 5.2 and $8.9 \%$, respectively. Hadjipanayiotou (1999) reported that the inclusion of olive cake silage in the diet of lactating Chios ewes, Damascus goats, and Friesian goats increased milk fat content. Improving milk fat concentration is mainly due to the enhanced digestibility of fiber and production of ruminal acetate; the main precursor for fat biosynthesis (Kholif et al., 2018 b; Abd El Tawab et al., 2020). In consistency with the present results, Cabiddu et al. (2004) and Abbeddou et al. (2011) reported no effect on milk composition with feeding lactating ewes on diets containing olive cake at 200 and $300 \mathrm{~g} /$ ewe, respectively. In another experiment, Vargas-Bello-Pérez et al. (2013) observed that including olive cake in the diet of sheep at 10 and $25 \%$ did not affect milk composition; however, total solids concentration increased with diet containing $25 \%$ olive cake.

\section{Conclusions}

Olive cake ensiled without or with fibrolytic enzymes can replace $30 \%$ of concentrates (equal to $18 \%$ of the total diet) in the diet of lactating Barki ewes. The inclusion of olive cake did not affect feed intake, enhanced nutrient digestibility and ruminal fermentation and increased milk yield. Ensiling of olive cake with fibrolytic enzyme showed better performance compared with ensiling it without fibrolytic enzymes, but the differences were insignificant; therefore, the enzyme treatment of olive cake has no advantages. However, additional studies, involving in vitro and in vivo evaluations, are recommended to investigate different levels of treated olive cake on the performance of animals at different stages of production. 


\section{References}

Abbeddou S., Ris chkows ky B., Richter E.K., Hess H.D., Kreuzer M., (2011). Modification of milk fatty acid composition by feeding forages and agro-industrial byproducts from dry areas to Awassi sheep. J. Dairy Sci., 94: 4657-4668.

Abd El Taw ab A.M., Matloup O.H., Kholif A.M., Abo E1-Nor S.A.H., Murad H.A., E 1 - S a y e d H.M., K h o r s h e d M.M. (2015). Influence of addition of tannase enzyme to reducing tannins effects in lactating goats diets. Int. J. Dairy Sci., 10: 24-35.

Abd E1 Tawab A.M., Kholif A.E., Has san A.M., Matloup O.H., Abo E1-Nor S.A., $\mathrm{O} l \mathrm{a}$ fa d e han O.A., K h a t t a b M.S.A. (2020). Feed utilization and lactational performance of Friesian cows fed beet tops silage treated with lactic acid bacteria as a replacement for corn silage. Anim. Biotechnol., 31: 473-482.

A b d e l- A zi z N.A., S a le m A.Z.M., E 1 - A d a w y M.M., C a m a cho L.M., Kholif A.E., E1 ghand our M.M.Y., B orhami B.E. (2015). Biological treatments as a mean to improve feed utilization in agriculture animals-An overview. J. Integr. Agric., 14: 534-543.

A b o E 1 - N or S.A.H., K h a t t a b M.S.A. (2012). Enrichment of milk with conjugated linoleic acid by supplementing diets with fish and sunflower oil. Pakistan J. Biol. Sci., 15: 690-693.

AOAC (1997). Official Methods of Analysis, 16th ed. Association of Official Analytical Chemists, Washington, DC, USA.

Aw a w d e h M.S., O b e i d a t B.S. (2013). Treated olive cake as a non-forage fiber source for growing awassi lambs: Effects on nutrient intake, rumen and urine $\mathrm{pH}$, performance, and carcass yield. Asian-Austral. J. Anim. Sci., 26: 661-667.

Azzaz H.H., Kholif A.E., Abd El Tawab A.M., Khattab M.S.A., Murad H.A., Olafa d e h a n O.A. (2020). A newly developed tannase enzyme from Aspergillus terreus versus commercial tannase in the diet of lactating Damascus goats fed diet containing pomegranate peel. Livest. Sci., 241: 104228.

B e r b e l J., P o s a dillo A. (2018). Review and analysis of alternatives for the valorisation of agroindustrial olive oil by-products. Sustain, 10: 237.

Cabiddu A., C an u M., D e c andia M., Pompei R., Molle G. (2004). The intake and performance of dairy ewes fed with different levels of olive cake silage in late pregnancy and suckling periods. In: Nutrition and feeding strategies of sheep and goats under harsh climates, Ben Salem $\mathrm{H}$., Nefzaoui A., Morand-Fehr P. (eds). CIHEAM, Zaragoza, Spain, pp. 197-201.

Ch i o fal o B., L i o t t a L., Z u m b o A., C h i o fa 1 o V. (2004). Administration of olive cake for ewe feeding: Effect on milk yield and composition. Small Rumin. Res., 55: 169-176.

Elghandour M.M.Y., Kholif A.E., Márquez-Molina O., Vázquez-Armijo J.F., P un i y a A.K., S a le m A.Z.M. (2015). Influence of individual or mixed cellulase and xylanase mixture on in vitro rumen gas production kinetics of total mixed rations with different maize silage and concentrate ratios. Turkish J. Vet. Anim. Sci., 39: 435-442.

Elghandour M.M.Y., Kholif A.E., Hernández J., Mariezcurrena M.D., López S., C a m a c ho L.M., Má r qu e z O., S a l e m A.Z.M. (2016). Influence of the addition of exogenous xylanase with or without pre-incubation on the in vitro ruminal fermentation of three fibrous feeds. Czech J. Anim. Sci., 61: 262-272.

F erret A., P la ix ats J., Caja G., Gas a J., Prió P. (1999). Using markers to estimate apparent dry matter digestibility, faecal output and dry matter intake in dairy ewes fed Italian ryegrass hay or alfalfa hay. Small Rumin. Res., 33: 145-152.

F ir k in s J.L. (1997). Effects of feeding nonforage fiber sources on site of fiber digestion. J. Dairy Sci., 80: 1426-1437.

F 1 a t t W.P., Wa r n e r R.G., L o o s 1 i J.K. (1956). Absorption of VFA from reticulo-rumen of young dairy calves. J. Exp. Biol., 25: 928.

H a b e e b A.A.M., Gad A.E., E 1 - Tarabany A.A., Mus t a fa M.M., A t t a M.A. (2017). Using of olive oil by-products in farm animals feeding. Int. J. Sci. Res. Sci. Technol., 3: 57-68.

H a d j i p a n a y i o t o u M. (1999). Feeding ensiled crude olive cake to lactating Chios ewes, Damascus goats and Friesian cows. Livest. Prod. Sci., 59: 61-66.

H un t ing t o n G.B., H a r m o n D.L., R i c h a r d s C.J. (2006). Sites, rates, and limits of starch digestion and glucose metabolism in growing cattle. J. Anim. Sci., 84 Suppl: E14-E24. 
K e l e ş G. (2015). Zeytin Posasının Ruminantlar İçin Besin ve Besleme Değeri (The nutritive and feeding value of olive cake for ruminants). Turkish J. Agric. - Food Sci. Technol., 3: 780.

K h a t tab M.S.A., E 1 Taw ab A.M.A. (2018). In vitro evaluation of palm fronds as feedstuff on ruminal digestibility and gas production. Acta Sci. - Anim. Sci., 40: 39586.

Khattab H.M., Gado H.M., Kholif A.E., Mansour A.M., Kholif A.M. (2011). The potential of feeding goats sun dried rumen contents with or without bacterial inoculums as replacement for berseem clover and the effects on milk production and animal health. Int. J. Dairy Sci., 6 : $267-277$.

Khat tab H.M., Gado H.M., S a le m A.Z.M., C a ma cho L.M., E 1-S a y ed M.M., Kholif A.M., E 1 - S h e w y A.A., K h o 1 if A.E. (2013). Chemical composition and in vitro digestibility of Pleurotus ostreatus spent rice straw. Anim. Nutr. Feed Technol., 13: 507-516.

Khattab M.S.A., A b d E 1 Taw ab A.M., Fou ad M.T. (2017). Isolation and characterization of anaerobic bacteria from frozen rumen liquid and its potential characterizations. Int. J. Dairy Sci., 12: $47-51$

Khattab M.S.A., Azzaz H.H., Abd El Tawab A.M., Murad H.A. (2019). Production optimization of fungal cellulase and its impact on ruminal degradability and fermentation of diet. Int. J. Dairy Sci., 14: 61-68.

K h o lif A.E. (2019). Glycerol use in dairy diets: A systemic review. Anim. Nutr., 5: 209-216.

Kholif A.E., Khattab H.M., E1-Shewy A.A., Salem A.Z.M., Kholif A.M., E1-S ayed M.M., Gado H.M., Mariezcurrena M.D. (2014). Nutrient digestibility, ruminal fermentation activities, serum parameters and milk production and composition of lactating goats fed diets containing rice straw treated with Pleurotus ostreatus. Asian-Austral. J. Anim. Sci., 27: 357-364.

Kholif A.E., A b d o M.M., A ne le U.Y., El-S a y e d M.M., M or s y T.A. (2017 a). Saccharomyces cerevisiae does not work synergistically with exogenous enzymes to enhance feed utilization, ruminal fermentation and lactational performance of Nubian goats. Livest. Sci., 206: 17-23.

Khol if A.E., Elgh and o u r M.M.Y., R od ríguez G.B., Ol a fa d e han O.A., S a le m A.Z.M. (2017 b). Anaerobic ensiling of raw agricultural waste with a fibrolytic enzyme cocktail as a cleaner and sustainable biological product. J. Clean. Prod., 142: 2649-2655.

Kholif A.E., Gouda G.A., Anele U.Y., Galy e an M.L. (2018 a). Extract of Moringa oleifera leaves improves feed utilization of lactating Nubian goats. Small Rumin. Res., 158: 69-75.

K h o l if A.E., G o u d a G.A., O l a fa d e ha n O.A., A b d o M.M. (2018 b). Effects of replacement of Moringa oleifera for berseem clover in the diets of Nubian goats on feed utilisation, and milk yield, composition and fatty acid profile. Animal, 12: 964-972.

Kholif A.E., Kassab A.Y., Azzaz H.H., Matloup O.H., Hamdon H.A., Ola fadeh a n O.A., M or s y T.A. (2018 c). Essential oils blend with a newly developed enzyme cocktail works synergistically to enhance feed utilization and milk production of Farafra ewes in the subtropics. Small Rumin. Res., 161: 43-50.

Kholif A.E., Hassan A.A., El A shry G.M., Bakr M.H., E1-Zaiat H.M., Olafadeh a n O.A., M a 1 l o u p O.H., S a 11 a m S.M.A. (2021). Phytogenic feed additives mixture enhances the lactational performance, feed utilization and ruminal fermentation of Friesian cows. Anim. Biotechnol. In Press. https://doi.org/10.1080/10495398.2020.1746322

Linn J.G. (1974). Amphibians. In: Amphibians. National Academy of Sciences, Washington, DC, USA, pp. 224-241.

L u C.D., K a w a s J.R., M a h g o u b O.G. (2008). Recent advancements in fiber digestion and utilization in goats. Trop. Subtrop. Agroecosystems, 9: 65-72.

M i oč B., P a vić V., Vnuč e c I., Pr p i ć Z., K o s te li ć A., S u š ić V. (2007). Effect of olive cake on daily gain, carcass characteristics and chemical composition of lamb meat. Czech J. Anim. Sci., 52: 31-36.

Molina - A l c a i de E., Y áñ e z - R u iz D.R. (2008). Potential use of olive by-products in ruminant feeding: A review. Anim. Feed Sci. Technol., 147: 247-264.

Mors y T.A., Kholif S.M., Kholif A.E., Matloup O.H., S a lem A.Z.M., Abu Ele lla A. (2015). Influence of sunflower whole seeds or oil on ruminal fermentation, milk production, composition, and fatty acid profile in lactating goats. Asian-Austral. J. Anim. Sci., 28: 1116-1122.

Mors y T.A., Kholif A.M.A.E., Khol if S.M., Khol if A.M.A.E., S un X., S a lem A.Z.M. 
(2016). Effects of two enzyme feed additives on digestion and milk production in lactating Egyptian buffaloes. Ann. Anim. Sci., 16: 209-222.

Mors y T.A., Kholif A.E., M a tloup O.H., A bu Elella A., Anele U.Y., C at on J.S. (2018). Mustard and cumin seeds improve feed utilisation, milk production and milk fatty acids of Damascus goats. J. Dairy Res., 85: 142-151.

M o s s A.R., J o u a y y J.P., N e w b o ld J. (2000). Methane production by ruminants: Its contribution to global warming. Anim. Res., 49: 231-253.

Nefza ou i A., Van be 11 e M. (1986). Effects of feeding alkali-treated olive cake on intake, digestibility and rumen liquor parameters. Anim. Feed Sci. Technol., 14: 139-149.

NRC (2007). Nutrient Requirements of Small Ruminants, National Academies Press. https://doi. org/10.17226/11654

O l a fa deh a n O., A d e w u mi M., O ku n a d e S. (2014). Effects of feeding tannin-containing forage in varying proportion with concentrate on the voluntary intake, haematological and biochemical indices of goats. Trakia J. Sci., 12: 73.

Rig o u t S., Hurta u d C., L e m o s c ju et S., B a c h A., R u l qu in H. (2003). Lactational effect of propionic acid and duodenal glucose in cows. J. Dairy Sci., 86: 243-253.

Rivero N., S a lem A.Z.M., Ayala M., Elghandour M.M.Y., Kholif A.E., B a rbabos a A., Cam a cho L.M., R oj a s S., Olivares-Pérez J., Cipriano M. (2016). Influence of Salix babylonica extract, exogenous enzyme of xylanase and their combination on blood haematological and biochemical profile in sheep and goats. Indian J. Anim. Sci., 86: 1140-1144.

Rojo R., Kholif A.E., S a le m A.Z.M., Elghandour M.M.Y., Od ongo N.E., Montes de O c a R., R i v e r o N., A l o n s o M.U. (2015). Influence of cellulase addition to dairy goat diets on digestion and fermentation, milk production and fatty acid content. J. Agric. Sci., 153: 1514-1523.

Ry le M., Ørs k ov E.R. (1990). Energy nutrition in ruminants. Springer Netherlands, Switzerland AG. https://doi.org/10.1007/978-94-009-0751-5

S a $1 \mathrm{em}$ A.Z.M., A 1 s e r s y H., C a ma cho L.M., E1-A d aw y M.M., E $1 \mathrm{~g} h \mathrm{and}$ our M.M.Y., Kholif A.E., Rivero N., A lons o M.U., Zaragoza A. (2015 a). Feed intake, nutrient digestibility, nitrogen utilization, and ruminal fermentation activities in sheep fed Atriplex halimus ensiled with three developed enzyme cocktails. Czech J. Anim. Sci., 60: 185-194.

S a $1 \mathrm{e} \mathrm{m} \mathrm{A.Z.M.,} \mathrm{A} \mathrm{m} \mathrm{m} \mathrm{a} \mathrm{r} \mathrm{H.,} \mathrm{K} \mathrm{h} \mathrm{o} 1$ i f A.E., E $1 \mathrm{~g}$ h a n d o u r M.M.Y., Ort i z L.B. (2015 b). Effect of glucoamylase enzyme extract on in vitro gas production and degradability of two diets with $25 \%$ of corn or sorghum grains. Indian J. Anim. Sci., 85: 183-188.

S a le s J., J a n s s e n s G.P.J. (2003). Acid-insoluble ash as a marker in digestibility studies: A review. J. Anim. Feed Sci., 12: 383-401.

S a 11 a m S.M.A., Kholif A.E., A m in K.A., Nour El-D in A.N.M., A t ti a M.F.A., Mat lo u p O.H., A n e l e U.Y. (2020). Effects of microbial feed additives on feed utilization and growth performance in growing Barki lambs fed diet based on peanut hay. Anim. Biotechnol., 31: 447-454.

$\mathrm{S}$ a t t e r L.D., S ly t e r L.L. (1974). Effect of ammonia concentration on rumen microbial protein production in vitro. Brit. J. Nutr., 32: 199-208.

S j a unj a L.O., B a evre L., Junk karinen L., P eders en J., S e t a la J. (1991). A Nordic proposal for an energy corrected milk (ECM) formula EAAP Publication 50: Performance Recording of Animals. EAAP Publ., 50: 156-157.

Togtokhbayar N., Cerrillo M.A., Rodríguez G.B., Elghandour M.M.Y., Sale m A.Z.M., Urankhaich C., Jigjidpurev S., Odongo N.E., Kholif A.E. (2015). Effect of exogenous xylanase on rumen in vitro gas production and degradability of wheat straw. Anim. Sci. J., 86: 765-771.

Tyrre 11 H.F., Reid J.T. (1965). Prediction of the energy value of cow's milk. J. Dairy Sci., 48: 1215-1223.

Vald e s K.I., S a le m A.Z.M., L o pez S., A lon s o M.U., Rive ro N., Elghand our M.M.Y., D o mínguez I.A., R on quillo M.G., K h o lif A.E. (2015). Influence of exogenous enzymes in presence of Salix babylonica extract on digestibility, microbial protein synthesis and performance of lambs fed maize silage. J. Agric. Sci., 153: 732-742.

Van Soest P.J., Roberts on J.B., Lew is B.A. (1991). Methods for dietary fiber, neutral detergent fiber, and nonstarch polysaccharides in relation to animal nutrition. J. Dairy Sci., 74: 3583-3597. 
Vargas-Bello-Pérez E., Vera R.R., Aguilar C., Lira R., Peña I., Fernández J. (2013). Feeding olive cake to ewes improves fatty acid profile of milk and cheese. Anim. Feed Sci. Technol., 184: 94-99.

Wang Y., McAllister T.A., Rode L.M., B e a u chemin K.A., Morgavi D.P., N sere k o V.L., I w a a s A.D., Yang W. (2001). Effects of an exogenous enzyme preparation on microbial protein synthesis, enzyme activity and attachment to feed in the Rumen Simulation Technique (Rusitec). Brit. J. Nutr., 85: 325-332.

Yang W.Z., B e a u ch e m in K.A., R o d e L.M. (1999). Effects of an enzyme feed additive on extent of digestion and milk production of lactating dairy cows. J. Dairy Sci., 82: 391-403.

Received: 13 VIII 2020

Accepted: 17 XI 2020 